\title{
Anti-Americanism in Europe: Theoretical Mechanisms and Empirical Evidence
}

\author{
Heiko Beyer ${ }^{1, \star}$ and Ulf Liebe ${ }^{2}$
}

\begin{abstract}
One of the most popular explanations for post-9/11 anti-Americanism argues that resentment against America and Americans is mainly a function of the US government's unpopular actions. The present article challenges this interpretation: first, it argues that neither the vitality of the resentment in times when the United States had no influence in the respective parts of the world nor its recent radical manifestations are accounted for in a political reductionist framework. In fact, specific traditions of anti-Americanism have an influence on the negative attitudes observed today, as a comparison between Britain, France, Germany, and Poland reveals. Second, this article suggests an alternative theoretical approach. Anti-Americanism can be explained by two basic mechanisms: it functions as a strategy to project denied and disliked self-concepts onto an external object, and it offers an interpretation frame for complex social processes that allows to reduce cognitive dissonance. Multivariate analyses based on empirical data collected in the Pew surveys of 2002 and 2007 show the fruitfulness of our theoretical approach.
\end{abstract}

\section{INTRODUCTION}

In the past decade, aversion to the United States has gained such popularity that some commentators suspect we are facing the beginning of an 'anti-American century' (Krastev, 2004). If this is the case, the attacks of 9/11, the Afghanistan and Iraq wars, and the transatlantic diplomatic tensions of the past decade mark the beginning of a continuing escalation between the United States and a heterogeneous group including radical terror networks and anti-American publics or governments in different parts of the world.

Although anti-Americanism is not a new phenomenon to scholars of European societies (Markovits, 1985; Spiro, 1988; Hollander, 1992), its development since the breakdown of the communist bloc has been a relevant one. As most political scientists suggest, the United States became the sole global superpower by the past decade of the 20th century (Bacevich, 2002). And although its economic and even military capabilities seem to have been stretched to their limit, its soft power (Nye, 2004) remains strong.

Against this background one intuitive answer to the question why the United States is so strongly disliked in some parts of the world today refers to its hegemonic role in world politics and economics. Building on this assumption, some scholars argue that anti-Americanism is a response to actions performed by the United States (Cunliffe, 1986; Fabbrini, 2004; Nolan, 2005; Kohut and Stokes, 2006; Friedman, 2008; Holsti, 2008). Such an approach, however, seems unsatisfactory for two reasons: although anti-Americanism today is not completely detached from US policies and their consequences, a strictly pragmatic approach can neither explain the vitality of the resentment in times when the United States had virtually no influence in the respective parts of the world (which is to say: the greater part of its history) nor can it account for its radical manifestations.

The aim of this article is thus to transcend a mere political concept of anti-Americanism. To explicate our argument that the latter is unable to deal with the phenomenon adequately, we commence with a short conceptual clarification. We subsequently offer a historical overview that discloses the irrational 'surplus' (Berman, 2008) of today's aversion against 'America' because it shows that anti-Americanism existed long before the United States had any global influence. If we compare the specific traditions of the resentment in

\footnotetext{
${ }^{1}$ Georg-August-Universität Göttingen, Platz der Göttinger Sieben 5, 37073 Göttingen, Germany; and

${ }^{2}$ Universität Bern, Fabrikstrasse 8, 3012 Bern, Switzerland. *Corresponding author. Email: hbeyer@uni-goettingen.de; ulf.liebe@soz.unibe.ch
} 
Britain, France, Germany, and Poland with the recent trends for the years 2002-2010, we find that the chronicles of anti-Americanism have an influence on the recent perception of the United States and of Americans: Germany and France, compared with Britain and especially Poland, have a stronger history of anti-Americanism and also show stronger negative opinions on Americans and the United States today.

In the second half of the article, we outline explanatory mechanisms, derive hypotheses, and test them with multivariate analyses. The theoretical approach is based on an interpretation of the phenomenon that assumes that anti-American attitudes are based on individual perceptions of domestic developments rather than on the bilateral relations as such (Hollander, 1992; Diner, 1996; Roger, 2005; Markovits, 2007a; Berman, 2008). We add to this research by sketching out two mechanisms underlying anti-American attitudes. First, we assume that anti-Americanism is constituted by a projection of denied and disliked self-concepts. Negative aspects of the self (e.g. 'materialism', 'egoism', 'hedonism') are externalized and projected onto 'Americans', so that aggression is canalized. Second, on a cognitive level, social phenomena associated with the denied traits (e.g. 'capitalism', 'modernity', 'globalization') are identified with 'America'. Anti-Americanism offers an interpretation frame for complex social processes and functions as a Manichean worldview that allows to reduce cognitive dissonance. Both mechanisms-projection and the reduction of cognitive dissonance-presumably complement each other and are empirically expressed in the correlation of anti-American attitudes and discontent with capitalism, modernity, and globalization. The according hypotheses prove to be relevant, as multivariate regression analyses for the years 2002 and 2007 and for the countries Britain, France, Germany, and Poland show. ${ }^{1}$

After having elucidated the empirical data, the article closes with a discussion of the findings in the light of previous research, providing suggestions for further study.

\section{On the Concept of Anti-Americanism}

That our article intends to overcome a certain political reductionism in the field of anti-Americanism research is not to say that scholars are generally unaware of the distinction between criticism of policies and actions pursued by the United States and coherent negative antiAmerican attitudes or resentment. ${ }^{2}$ In fact, many do distinguish between both (Katzenstein and Keohane,
2007; Markovits, 2007a; Chiozza, 2009; Meunier, 2012). The problem lies more in the application of the concept. Most of the phenomena discussed and data used (be it items in surveys, newspaper articles, or parliamentary debates) are a mere expression of 'opinion' rather than of 'bias' (Katzenstein and Keohane 2007: p. 22) and refer to explicitly political phenomena. If the term 'antiAmericanism' is used inappropriately, although it may still be clearly defined, findings and conclusions are distorted.

We therefore advocate using the term 'antiAmericanism' solely for coherent negative attitudes (Eagly and Chaiken, 1993). We understand antiAmerican attitudes to be a psychological tendency to devalue actors and phenomena perceived as 'American'. This concept is not very different from the one suggested by Katzenstein and Keohane (2007: p. 12) in their important volume, ${ }^{3}$ but it puts more emphasis on the projective character of anti-Americanism: anti-American attitudes are to a certain extent independent from actual developments within American society: objects are even perceived as 'American' irrespective of whether (like the TV show Big Brother for example) they actually are American. It follows that our concept of 'antiAmericanism' is not restricted to political issues. It also captures a negative evaluation of economic aspects and cultural subjects such as language, sports, academia (Markovits, 2007a), and even topics such as 'obesity' (Saguy, Kjerstin and Gong, 2010).

In general, although there might be an empirical overlap of anti-Americanism and criticism of policies of the United States, empirical studies have to aim for a clear distinction between both phenomena. The main criterion is that of coherence: an individual is to be labelled 'anti-American' only if we find a coherent attitude structure. ${ }^{4}$ This is not necessarily in opposition to the finding of Chiozza (2009) that many individuals hold ambivalent rather than outright negative attitudes. This seems to be the case for the majority of people. In our understanding, however, these individuals should not be labelled '(manifest) anti-American'. This is not to say that such individuals do not participate in an antiAmerican discourse with certain utterances. But on a conceptual level, one has to keep in mind the analytical distinction between attitudes and discourse.

\section{A Short History of European Anti-Americanism}

Historical studies on anti-Americanism have emphasized that the origins of anti-Americanism can be found in Western Europe's late Romantic epoch-mainly in 
France and Germany (Ceaser, 2004), but also to some extent in Britain (Gulddal, 2009). ${ }^{5}$ At the end of the 18th century, 'America' - the 'new world'-had become very much a utopia for many Europeans. Along with high hopes, resentment also arose and the roots of this can be found in an aristocratic or elitist anti-democratic impulse against 'mass society', 'superficiality', and 'materialism'. This applies both to the political right (e.g. Nikolaus Lenau and Joseph de Maistre) and the left (e.g. Heinrich Heine and Voltaire; see Diner, 1996, for Germany, and Roger, 2005, for France). In France and Germany, opponents and supporters of the French Revolution in 1789 declared 'America' to be either a frightening example of what Europe could become if the Enlightenment took hold, or a society that would be too democratic and in which the noblesse of the European intelligentsia would get lost (Ceaser, 2004; Roger, 2005). 'Degeneration' presents the general narrative during that time with regard to the new continent. Not only were the natural surroundings, including animals and plants, perceived as inferior compared with those of Europe, but 'the Americans' themselves and the political institutions of the new nation were considered to be deformed, weak, and fragile (Ceaser, 2004; Roger, 2005; Markovits, 2007a).

After World War I, anti-Americanism gained anticapitalist and anti-imperialist connotations. The tense relation with anti-Semitism was also forged in that era. A vivid illustration of this development represents the image of President Wilson at that time (Diner, 1996). Wilson-with his 'American character'-symbolized what Europeans feared most: the alienation and modern abstractness that 'the American way of life' (and thinking) was supposed to bring to Europe. His alleged 'Jewishness' (Wilson was actually Presbyterian) supposedly proved that America was controlled by Jews. During the 1920s, Germany in particular experienced a huge push for modernization. The rapid political and cultural changes, perceived as 'Americanization', led to a growing 'Überfremdungsangst' (fear of foreign infiltration) and 'Unbehagen in der Kultur' (civilization and its discontents; Lit: uneasiness in culture, see Freud, 1930/ 1997). ${ }^{6}$ In this context, racist, anti-Semitic, and anticapitalist connotations were merged (Schwaabe, 2003).

A more radical form of this mainly economic antiAmericanism could be found in Nazi Germany. After years of tactical reserve and even appreciative interest in the technical know-how of the United States (especially in radio and cinema), the Nazis increasingly included anti-American content in agitations (Diner, 1996; Schwaabe, 2003). America was seen as an instrument of Jewish capital employed to enslave the world. For that matter, together with Britain, the United States became the 'hoard of modern capitalism'-the ideological archenemy of National Socialism.

After World War II, a growing leftist form of antiAmericanism could be observed. In Western Germany, parts of the student movement exhibited anti-imperialist and anti-American mindsets (Diner, 1996; Schwaabe, 2003). America was considered largely responsible for warlike operations around the world-it was perceived as the number one enemy of world peace. Under these circumstances, an ironic shift took place: the United States was declared a fascist state, and criticism of the United States was part of an anti-fascist lesson from history. Diner (1996) considers this to be a psychologically functional process in the relativization of German guilt. But also in France, where parts of the communist left viewed the United States as the imperialist nation, 'America' was identified with capitalism in general (Roger, 2005). However, even when taking the politics of the left into account, French anti-Americanism had a more cultural drive.

In Britain, cases of anti-Americanism can be found throughout history, and the same 'snobbery' as in France or Germany was also articulated by British intellectuals (e.g. Charles Dickens), especially between 1815 and 1835 (Roger, 2005: pp. 48-51; Gulddal, 2009). However, compared with Germany and France, these were rather sporadic episodes. Anti-Americanism, despite being popular among the British left, did not become part of a 'cultural code' (Diner, 1996: p. 20; Volkov, 1978) like in large parts of continental Europe. The apparently close relations between the former colony and its colonist are based on a common Anglo-Saxon tradition of thought, even more than on political dependencies (Singh, 2007). Nevertheless, the Middle-East conflict has its impact on opinions of 'America', as a significant part of the British public is opposed to Israeli policies and holds the United States to a certain extent responsible for the development of the region (Mosbacher and Anderson, 2004).

Compared with Germany and France, Poland has little history of anti-Americanism because, disappointed with the developments in Europe, America seemed for the Poles a place of hope rather than of fear (Krzemiński, 2004; Behrends, 2005). Threatened by Russia and Prussia since the 18th century, and later by the USSR and Nazi Germany, the country developed a certain affinity with the United States. In fact, Poland can be considered one of the most pro-American countries in Europe (Antoszek and Delaney, 2006). No official anti-Americanism had developed before the influence of the Stalinist USSR (Behrends, 2005). The translation of Ilya Ehrenburg's work $V$ Amerike (In America), which was published in Poland under the title Wrócitem z USA (Back From the 
USA) only a year after the Russian original came out in 1947, was expressly intended to spread hostility against the United States in Poland. However, as mentioned previously, anti-American propaganda was confronted with a rather pro-American public.

This short historical excursion offers the basis for examining whether specific national or cultural developments affect the current aversion against 'America', which is often solely understood to be a response to the special position of the United States in world politics. Contrary to this perspective, prejudice and animosity were already visible in times when the new continent had virtually no influence on domestic relations in Europe. In the following section, we show how the legacies of anti-Americanism have impacted the resentment prevalent today (McAdam, 2007); collective memory preserves negative attitudes and influences current perception. Consequently, anti-Americanism can be assumed to be a path-dependent phenomenon.

\section{Recent Trends}

The more recent development of anti-Americanism is recorded, for example, in the Pew Global Attitudes Project Surveys. They use a constant set of questions about the 'favourability of the United States' and 'favourability of Americans' from 2002 to 2010 for various countries (www.pewglobal.org). ${ }^{7}$ Most researchers would agree that negative opinions towards Americans on the one hand and the United States on the other should be distinguished (Katzenstein and Keohane, 2007), and that the former can be considered a measure of anti-Americanism (Chiozza, 2008), while the latter is influenced by US foreign policies more strongly and thus is considered a measure of 'US-critique'. ${ }^{8}$ We are aware that such an operationalization, especially of the concept of anti-Americanism, is far from perfect, but unfortunately, a more nuanced measurement instrument is only available in the Pew data for the years 2002 and 2007. We will introduce this instrument later in the section on multivariate analyses.

Figure 1 shows descriptive results for the development of negative views of the United States and Americans between 2002 and 2010 in Britain, France, Germany, and Poland (cross-sectional data). Three external events have to be considered when interpreting the figures presented: the $9 / 11$ attacks of 2001, the Iraq war that started in 2003, and the election of Barack Obama as president in 2008. As much as the terrorist attacks on the World Trade Center and the Pentagon seemed to have closed the ranks within the 'Western world', leading to broad expressions of sympathy (but also to a lot of Schadenfreude) and a conjoint war in Afghanistan, the
Iraq intervention starting in March 2003 evoked an increasing alienation between parts of Europe and the United States. Both in France and in Germany, the political leadership began to use its criticism of the United States to win elections (Markovits, 2007a; Meunier, 2007), and even in Britain and Poland-US allies in the Iraq war-there were mass demonstrations against US policy. This almost consensual disaffirmation, mainly of the Bush administration, led to a great deal of enthusiasm for his 'antagonist', Barack Obama. Most importantly for the commentators, his election seemed to be a good sign that 'America is coming to its senses'.

In all four countries, unfavourability of the United States rose between 2003 and 2008. Britain shows values between 16 per cent and 42 per cent, France between 25 per cent and 62 per cent, Germany between 33 per cent and 66 per cent, and Poland between 11 per cent and 31 per cent. Differences between the countries are apparent. In all years, Germany and France show a remarkably higher percentage of critical opinions than Britain or Poland. The latter has a peak of 31 per cent in 2007, which does not even reach the lowest value of 33 per cent observed in Germany in 2009. But there are also similarities: In all four countries, negative opinions began to rise with the start of the Iraq war in 2003 and it was not until 2009, when Barack Obama took office, that values dropped again significantly (but not in Poland). The maximum difference in aversion to the United States over time varies between 20 per cent in Poland and 37 per cent in France.

The values for negative views of Americans are considerably lower than those for the United States. Again, France (between 26 per cent and 43 per cent) and Germany (between 23 per cent and 34 per cent) can be clearly distinguished from Poland (between 12 per cent and 26 per cent) and Britain (between 11 per cent and 22 per cent). On average, French and German interviewees reported a higher degree of anti-Americanism than their Polish and British counterparts. For all countries, the lowest values can be found in 2002, a year when solidarity with the victims of $9 / 11$ still seemed strong. The times of the respective turning points are indeed the years 2003 (after the beginning of the Iraq war) and 2009 (after Obama's election), although, as expected, the turning points are not that clear-cut compared to those regarding negative views of the US.

Comparing the country-specific differences over the years for both items, the fluctuation for negative 'opinions of Americans' is not as huge as for negative 'opinions of the United States': 11 per cent in Germany and Britain (compared with 33 per cent and 26 per cent, respectively), 14 per cent in Poland (compared with 20 per cent), and 17 per cent in France (compared with 37 

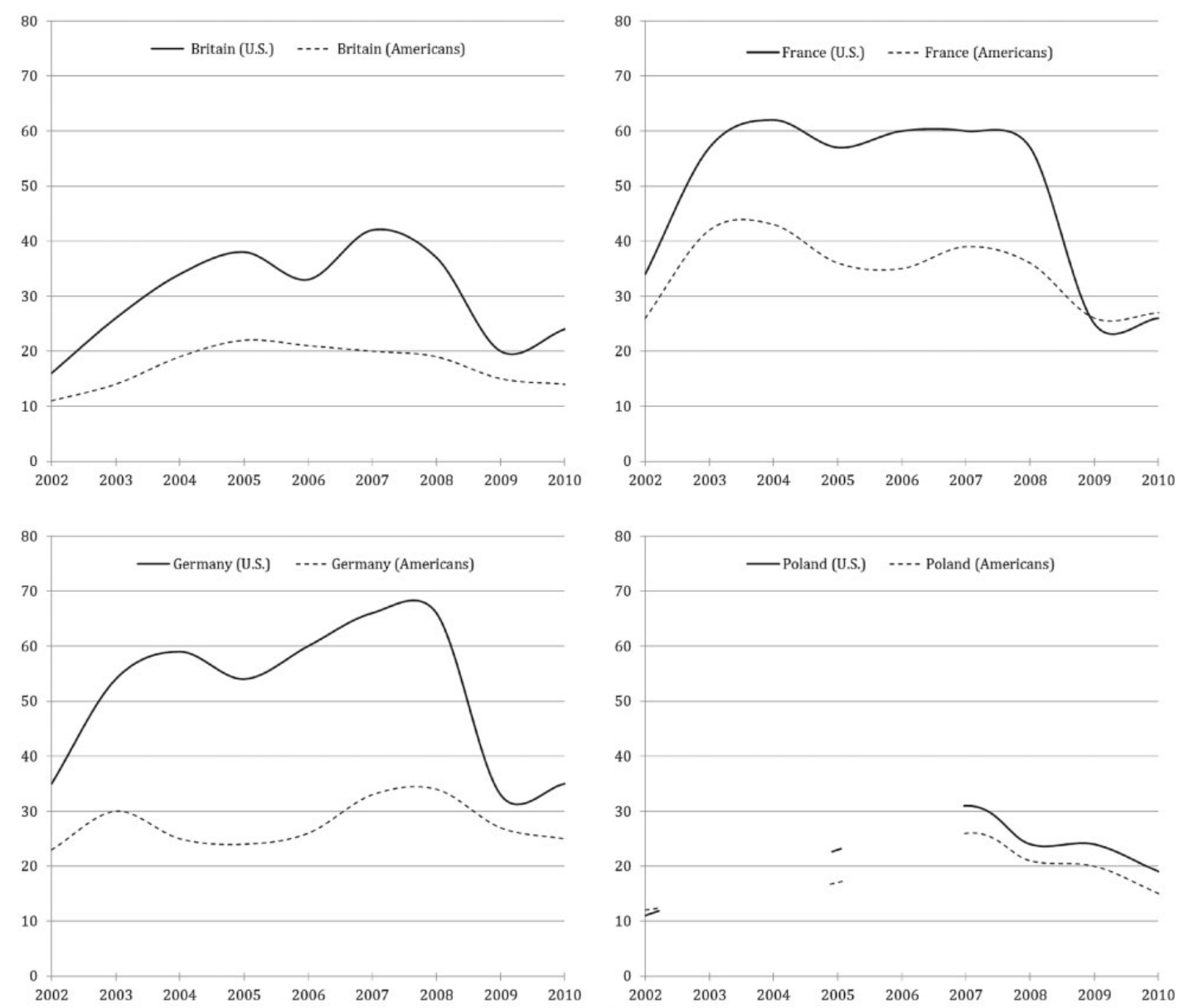

Figure 1 Proportion of negative opinions of the United States and Americans.

Notes: The continuous line refers to 'negative opinion of the United States' and the dashed line to 'negative opinion of Americans'. As there are no data for Poland for the years 2003, 2004, and 2006, final conclusions have to be drawn with caution. The number of cases varies for Britain between 458 in 2002 and 929 in 2007, for France between 488 in 2004 and 1002 in 2007, for Germany between 478 in 2003 and 967 in 2007, and for Poland between 443 in 2002 and 880 in 2005. With the exception of Britain, the minimum number of cases can always be found for the item about 'Americans' and maximum number for the item about 'the United States'. This is due to the fact that in almost all cases, the item about 'Americans' produces slightly more missing values

per cent). This can be interpreted as an indicator that indeed, as Chiozza (2008) suggests, the 'opinion about Americans', is less affected by external events such as political tensions. Our findings are also in line with others, showing that anti-Americanism did not vanish with Obama's election (Hatlapa and Markovits, 2010).

Concerning both the 'opinion of the US' and 'opinion of Americans', the differences are especially noteworthy for France and Germany. Not only is aversion to the United States indeed more closely connected to US policies than the aversion to Americans, but its ups and downs are most striking in the two countries with the highest absolute levels of negative opinions. This is an interesting finding, but how can it be explained? It is plausible that an 'amplification effect' is at work: the high level of aversion to the United States in 'better times' (here in 2002 when solidarity with the United States seemed strong), which by assumption stems from a deeper resentment, offers the basis for a stronger aversion in 'worse times' (here between 2003 and 2008). When a significant part of the population already feels antagonistic towards the United States, it is more likely 
that other people will join the bandwagon. This, of course, is a tentative explanation that has to be tested elsewhere.

In summary, the findings show on a descriptive level that external events have a considerably higher influence on negative opinions of the United States than on negative opinions of Americans. It is thus a shortcoming of recent research that negative opinions of the United States are frequently used as the operationalization of anti-American attitudes. Even if the item 'negative opinions of Americans' might entail an overestimation as well, it can be used as a better (tentative) proxy for anti-American resentment, especially in 'good times'. Having said this, we can conclude that the descriptive trend figures at hand mirror the suggested historical path dependencies resulting in higher levels of antiAmericanism in France and Germany compared with Britain and Poland. This can be taken as empirical support of McAdams' (2007) approach, which highlights specific legacies of anti-Americanism.

\section{What Drives Anti-Americanism?}

While for several countries specific genealogies of antiAmericanism, which account for the international peculiarities, can be found, systematic reflections on the theoretical mechanisms of the resentment in general-and in sociological works in particular-are rare (one exception is McAdams' contribution; McAdams, 2007). As we have mentioned, many explanations in recent works rest on a more or less subtle version of the assumption that anti-Americanism is a reaction to the peculiar position of the United States in world politics (Cunliffe, 1986; Fabbrini, 2004; Nolan, 2005; Kohut and Stokes, 2006; Friedman, 2008; Holsti, 2008). It is presumed that the aversion to the United States stems from its hegemonic character. Indeed, the most comprehensive feature of anti-Americanism among both the left and the right, Europeans, and people in the Middle East is to be found in the accusation of (political, economic, and cultural) imperialism.

However, the global political conditions as such cannot explain this anti-colonial connotation that, ironically, was introduced by the 18th-century European colonists. As we mentioned earlier, 'America' is not merely detested for what it does but for what it is supposed to be, namely, the hoard of modern, western, and capitalist thinking (Markovits, 2007a). Hollander (1992) has used the term 'scapegoating impulse' and Diner (1996) the term 'projection' to indicate that essentialistic resentment can only be explained if we focus on the societies and individuals where this resentment is prevalent. Keohane and Katzenstein
(2007: p. 6) make a similar point when they conclude 'non-Americans look to the United States as a mirror that reflects their own hopes, fears, and faults'. Chiozza's (2009) hypotheses (the information-and-contact, traditional-worldview, anti-market, and scapegoat hypotheses) also refer to deeper roots of anti-American resentment.

All those works, however, lack an explication of the theoretical mechanisms. The main aim of this section, and of this article overall, is therefore to suggest a tentative theoretical model of anti-Americanism. In particular, we will introduce the concept of pathic projection (Horkheimer and Adorno, 1947) and cognitive dissonance (Festinger, 1957/1985).

The former was developed in Horkheimer and Adornono's Dialectic of Enlightenment (1947). There 'pathic projection' denotes a psychological process constituting anti-Semitic resentment. The concept builds on Freudian theory ${ }^{9}$ complemented by a broader sociological framework and epistemological reflections. According to Horkheimer, Adorno, and Löwenthal (who co-authored the respective section), anti-Semitism is characterized by the suppression of certain libidinous drives and ego-centred desires due to an over-identification with normative imperatives of certain social institutions. In a process of externalization, the denied parts of the self are projected onto the Jews who supposedly have everything the anti-Semite unconsciously wishes for: '[...] happiness without power, wages without work, a home without frontiers, religion without myth' (Horkheimer and Adorno, 1947: p. 165). Formerly directed against the inner drives, the aggression is now directed against an outer object. The Jews are devalued and persecuted in place of the denied and disliked parts of the self.

This approach is applicable to the phenomenon of anti-Americanism. 'America' has been and continues to be a subject of admiration for many people. At times, this admiration is just as projective as undifferentiated hate against everything perceived as 'American'. No other country is so inherently associated with the concept of individual happiness and political freedom. In the context of societies where individuals show a tendency to feel threatened by those notions of freedom, we might observe a devaluation of hedonistic traits and aggressive outbursts against an outer entity associated with the suppressed traits. This is apparent in the case of radical Islamist anti-Americanism, where worldly lust is strictly dismissed, but it also holds true for 'postmaterialistic' (Inglehart, 1977) and hyper-moral fractions of Western societies. Here, the supposedly materialistic and egoistic 'Americans' mirror the unconscious basis of 'post-materialistic' moral codes and are thus detested for 
reminding the 'post-materialists' of their denied egoistic drives.

On an ideological level, the traits of 'materialism', 'egoism', and 'hedonism' refer to abstract concepts of 'capitalism' and 'modernity' in general, but also to the more recent concept of 'globalization' in particular. Here, a cognitive mechanism comes into play: the complexity of these processes is rationalized in the catchphrase 'Americanization'. 'America' is imagined to be the place where these processes originated. Being an everyday life theory, anti-Americanism has the benefit of 'explaining' an increasingly 'confusing world' (Claussen, 2007). The cognitive benefit of such a rationalization of abstract and confusing social processes lies in the generation of consistency and the elimination of 'cognitive dissonance' (Festinger, 1957/1985). A Manichean worldview such as anti-Americanism offers a clear-cut distinction between 'good' and 'bad', draws a simple picture of society, and consists of a fixed interpretative frame, nearly untouched by changes in reality.

Based on those two theoretical approaches, we can formulate the following two hypotheses: the hypothesis of social discontent states that the stronger the negative attitudes towards 'capitalism' and 'modernity' of an individual, the stronger are his/her anti-American attitudes. A derivative of this hypothesis is the hypothesis of globalization critique, which states that the stronger the negative attitudes towards 'globalization' of an individual, the stronger are his/her anti-American attitudes. Both the mechanism of projection and the mechanism of cognitive dissonance play a role in the underlying psychological processes. Unconsciously desired but superficially repelled traits are projected onto the 'Americans'. Aggression that was originally directed against parts of the self is now directed against an outer enemy. On a more abstract level, the denied traits are connected to disliked social processes ('capitalism', 'modernity', and 'globalization'), which are again identified with 'America' and thus externalized. The psychic benefit of this externalization lies in the reduction of complexity and cognitive dissonance.

The approach of pathic projection further implies that anti-American attitudes and anti-Semitic attitudes show a positive correlation because both have a functional similarity and both objects of projection (Jews and Americans) are attributed with similar stereotypical qualities (greedy, omnipotent, rational, etc.). ${ }^{10}$ The hypothesis of anti-Semitism thus states: the stronger the anti-Semitic attitudes of an individual, the stronger are his/her anti-American attitudes.

In line with the approach of cognitive dissonance is the contact hypothesis. Increasing contact with the reality of the United States would make it necessary to correct the homogenous picture of 'America' to reduce 'cognitive dissonance'. It can therefore be expected that antiAmerican attitudes are less strong if individuals have already visited the United States. ${ }^{11}$

In the following, we will present the respective multivariate models, which are also based on Pew data, to estimate the empirical validity of the proposed theoretical mechanisms and corresponding hypothesis.

\section{Multivariate Analyses}

Studies on anti-Americanism containing multivariate analyses are relatively new to the research field. Studies by Ray and Johnston (2007), Gentzkow and Shapiro (2004), Isernia (2007), and Chiozza (2009) are some of the few contributions to use regression models, although not all of these treat anti-Americanism as a dependent variable. Chiozza's study is currently probably the most advanced (quantitative) empirical work in the field. We treat his analyses as a solid basis and intend to complement them with a more explicit and elaborated theoretical framework (which suggests further explanatory variables) by choosing a more valid measurement of anti-Americanism as a dependent variable and by looking at two points in time. This approach will show whether Chiozza's (somewhat rash) judgement of antiAmericanism as 'too loose to be a well-knit ideology and too differentiated to be a cultural syndrome' (2009: p. 136) holds true when extending conceptual, theoretical, and methodological research.

What follows is a presentation of multivariate analyses for the years 2002 and 2007 and the countries Britain, France, Germany, and Poland, based on the Pew data. These points in time have been chosen for two reasons. First, given the Pew data between 2002 and 2010, the surveys carried out in 2002 and 2007 measure antiAmerican resentment more comprehensively and also best measure the theoretically derived determinants discussed in the previous section. Second, the consideration of two time points at least gives an impression of whether effects are stable over time. This might be especially interesting in the case at hand because, as illustrated in the descriptive analyses, the opinion of the United States and Americans in 2002 was favourable compared with 2007.

Compared with the rather simple questions regarding the favourability of the United States and Americans presented in the section on recent trends, the measurement instrument of anti-Americanism here consists of an additive index for the multivariate analyses. This index (ranging from $0=$ 'no anti-Americanism at all' to $3=$ 'high degree of anti-Americanism') is based on three questions answered in the Pew polls for 2002 and 


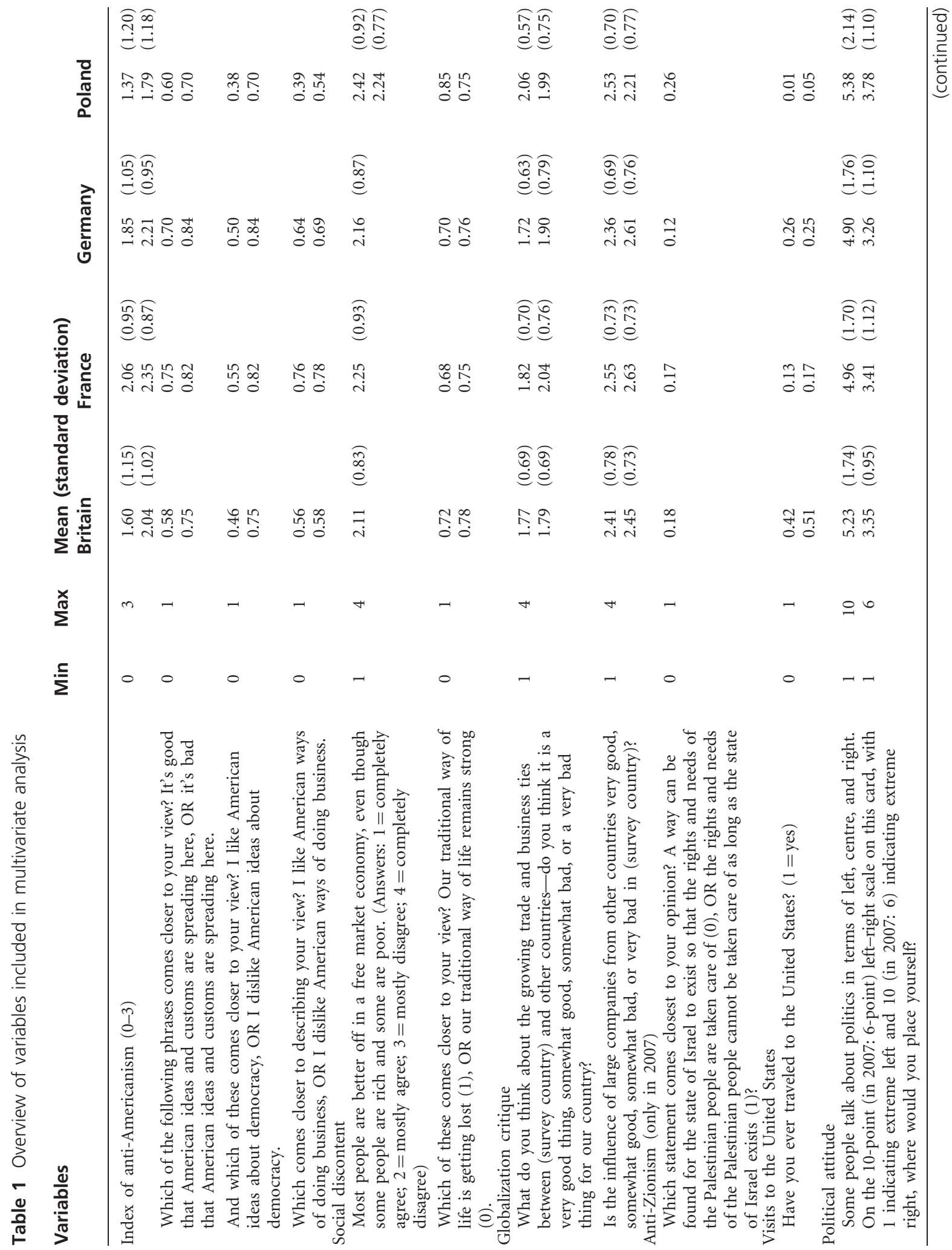




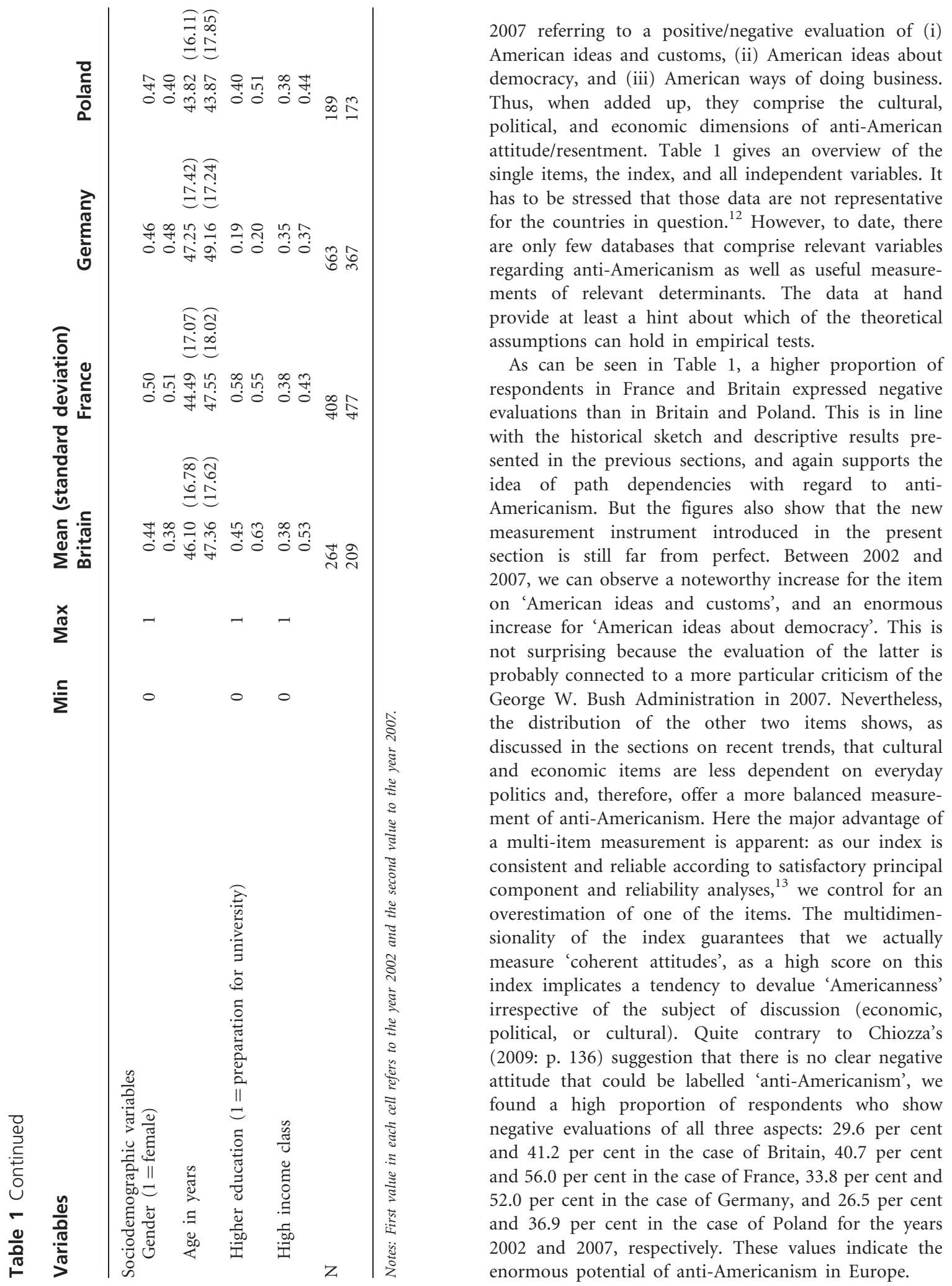


The independent variables are measured as follows: social discontent with 'capitalism' and 'modernity' is measured by means of two items: (i) for 2002, with an item concerning a positive opinion towards the institution of a free market economy that characterizes all four countries. Except for Poland, this item is not available in the 2007 data set. (ii) The other item focuses on the perceived loss of the traditional way of life. Although the common problem of distinguishing evaluative and descriptive dimensions of the item seems apparent here, we think it can be used as a proxy for discontent with modernization. In all four countries, a large majority of the respondents are convinced that the traditional way of life is in decline.

The measurement of globalization critique is also based on two items: first, on the trade and business networks between the respondent's home country and other countries, and second, on the influence of large foreign companies in the respondent's home country. As it turns out, in each of the four countries, respondents are more concerned about the influence of large foreign companies than growing business networks.

There is no item measuring genuine anti-Semitism in the Pew data. However, recent research on anti-Semitism has suggested that anti-Zionism can be considered a derivative of anti-Semitic thinking (Chesler, 2005; Hirsh, 2007). Keeping the data at hand in mind, we define antiZionism in this article as the denial of Israel's right to exist. There are, however, more 'elaborated' forms of anti-Zionism that do not necessarily deny Israel the right to exist but that use anti-Semitic stereotypes or have to be traced via their function in certain discourses. The item consists of the following wording: 'Which statement comes closest to your opinion? A way can be found for the state of Israel to exist so that the rights and needs of the Palestinian people are taken care of OR, the rights and needs of the Palestinian people cannot be taken care of as long as the state of Israel exists?' The proportion of respondents who can be classified as anti-Zionist varies between 12 per cent in Germany and 26 per cent in Poland.

There is also a remarkable variation between countries with regard to respondents who have already visited the United States at least once. The highest proportions can be observed for Britain and the lowest for Poland. The list of independent variables considered in the multivariate analysis also includes respondents' political attitudes, gender, age in years, whether respondents have secondary school education, and whether they belong to a high-income class (based on a median split of the original income variable).

The results of ordinary least square regression models are documented in Table $2 .{ }^{14}$ For each country, two models were estimated, one for the year 2002 and one for the year 2007. The first main hypothesis, the hypothesis of social discontent, is to some extent supported in all countries for the two points in time, with the exception of Britain in 2007. The stronger the respondents' negative opinion about the institution of a market economy, the higher their values on the antiAmericanism index in 2002. The coefficients are significant for Germany and Poland, while the coefficient for Britain just reaches the 10 per cent significance level, and for France, the effect is clearly non-significant. Moreover, respondents who perceive a loss of traditional ways of life also have significantly higher anti-Americanism values in France and Germany in both years and in Britain in 2002. While showing the expected positive sign, the coefficients for Britain in 2007 and for Poland in 2002 and 2007 are not statistically significant.

With regard to the hypothesis of globalization critique, more robust correlations with anti-Americanism can be observed for the item 'negative evaluations of the influence of large foreign companies in respondent's home country' compared with the item 'negative evaluation of growing business ties'. While the former shows positive and significant effects in all models, except for Germany in 2007, the latter has the expected positive sign, but it is only significant for Britain, France, and Germany in 2002.

There is a positive association between anti-Zionism and anti-Americanism in all four countries. For Germany and Poland, this positive correlation is also statistically significant. This supports the argument of several researchers who highlight the relationship between anti-Semitism and anti-Americanism (Diner, 1996; Haury, 2005; Markovits, 2007b; Knappertsbusch and Kelle, 2010). Here again, path dependencies might come into play. Poland with its strong history of anti-Semitism (Gross, 2007) but a relatively low degree of antiAmericanism is a case where anti-American attitudes are quite a new phenomenon. As the United States and Israel are considered close allies, it seems plausible that recent Polish anti-Americanism is triggered by negative attitudes towards Jews in general and Israel in particular. In Germany, where anti-Americanism has a long tradition that is based on the aforementioned anti-colonial complex and where genuine expressions of anti-Semitism in public are perceived to be a taboo, anti-Zionism together with anti-Americanism might be a way to communicate anti-Semitic attitudes indirectly (Bergmann and Heitmeyer, 2005).

The contact hypothesis is based on the assumption that anti-Americans have visited the United States less often than others because visits would increase cognitive dissonance. Here, causality can go in both directions. 


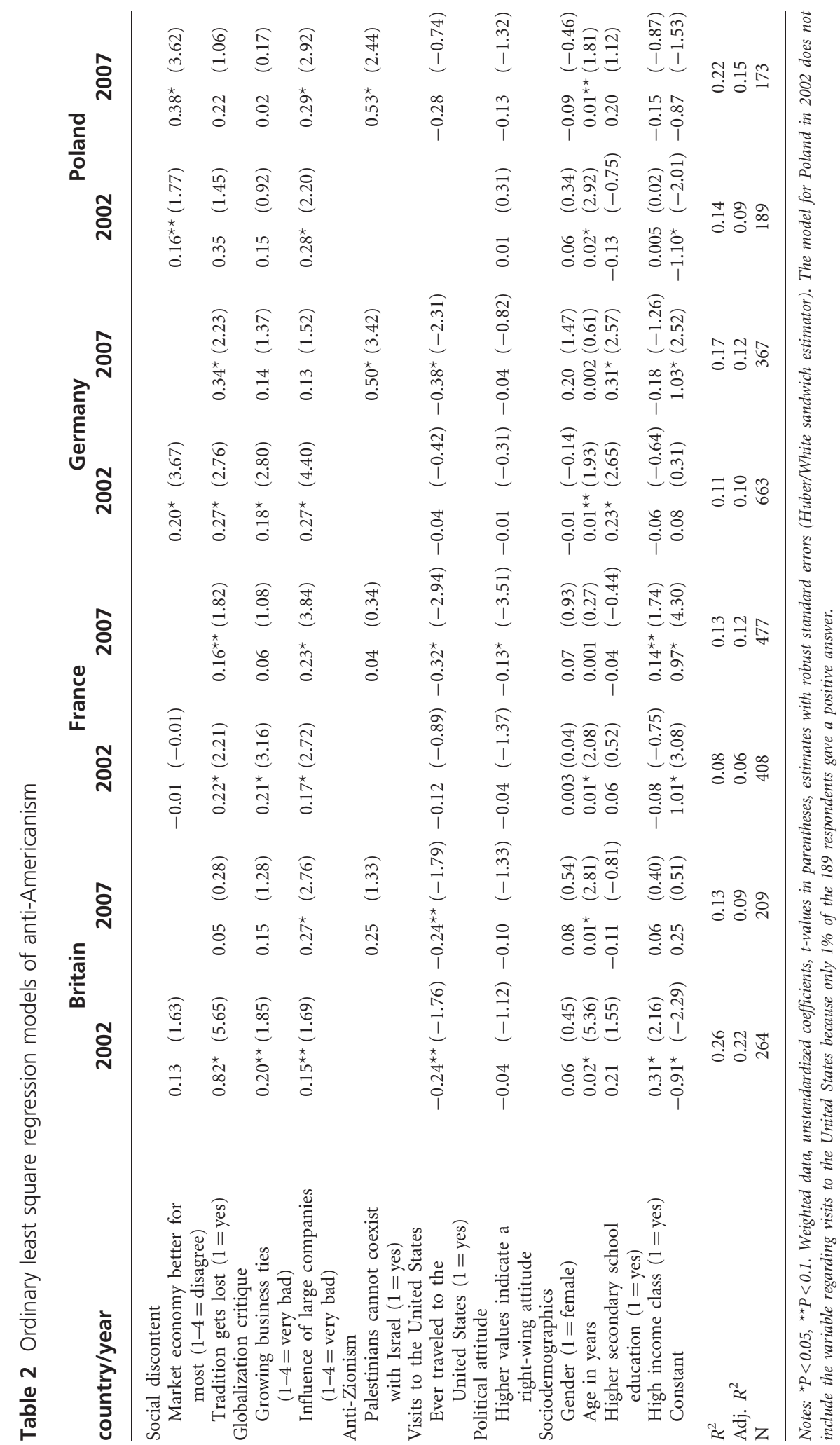


On the one hand, not having visited the United States will increase prejudice and on the other hand, individuals who have prejudices will avoid visiting the country. In all models, the hypothesis holds true with regard to the negative sign of the estimated coefficients; the effects are statistically significant for Britain in both years and for France as well as Germany in 2007.

The prevalence of anti-Americanism in certain political milieus has been another point of discussion in the literature. In this regard, we included respondents' political attitudes in the multivariate models. It seems there is an overall trend towards lower values on the anti-Americanism index for respondents with a rather right-wing attitude; yet, the effect is statistically significant in just one case (France in 2007). We also tested for a U-shaped correlation between political attitudes and anti-Americanism, that is, higher values of antiAmericanism from respondents with a strong left-wing or right-wing attitude. However, additional analyses do not support such a non-linear effect of the political attitude in six of eight models in Table 2. The two exceptions show that in Britain, the proposed U-shaped relation can be found in 2002, and in Poland, an unexpected inverted $U$-shaped relation can be found in 2007 (i.e. higher values more or less in the centre of the political spectrum). Hence, our data support Markovits and Rensmann's (2007) estimation that nowadays antiAmericanism has become an overlapping phenomenon that has lost its exclusivity in regard to the political 'extremes' in the past 10 years.

Among the sociodemographic variables, age is the only one to show a clear pattern. In all models, antiAmericanism significantly increases with respondents' age, with the exception of France and Germany in 2007. Gender, education, and income do not show noteworthy effects across the four countries. The findings indicate, however, a positive and significant effect of education for Germany: higher educated respondents were found to express higher values of anti-Americanism. This is in line with qualitative research that has highlighted that antiAmericanism is most common among members of Germany's intellectual elite (Markovits, 2007a).

Overall, the presented multivariate results provide rather strong support for the hypotheses of social discontent and globalization critique across the four countries and the two points in time. This can be considered an indication that both the mechanism of projection and the mechanism of cognitive dissonance offer explanations that are valid over time. Further, the contact hypothesis has a high plausibility, that is, correlations are negative as predicted and significant for at least one point in time for Britain, France, and Germany. A striking difference between the four countries can be found with regard to the association between anti-Semitism/anti-Zionism and antiAmericanism. There are positive and significant effects in Germany and Poland, whereas the effects are clearly below the significance threshold in both Britain and France.

The explained variance of the models ranges between 6 per cent and 22 per cent. Such values are common in social science research, but they clearly point to additional explanatory factors. Another reason for the lack of explained variance may be that the measurement instruments considered in the Pew data do not fully match the theoretical concepts, neither 'antiAmericanism' nor 'social discontent' and 'globalization critique'.

\section{Discussion and Conclusions}

The findings of this article shed new light on the assumptions made in anti-Americanism research to date. First of all, we have demonstrated that negative views today are dependent on the specific historical traditions of the resentment: if a country has a strong history of anti-Americanism (such as Germany or France), higher levels of negative attitudes can be reported compared with countries that do not have such a history (especially Poland). Against this background, it seems highly problematic to consider anti-Americanism simply as a function of recent political conflicts (Cunliffe, 1986; Fabbrini, 2004; Nolan, 2005; Kohut and Stokes, 2006; Friedman, 2008; Holsti, 2008).

Furthermore, we have challenged the statement that anti-Americanism cannot be considered a consistent attitude (e.g. Chiozza, 2009). Although it might be true that many individuals have rather conflicting views on Americans and the United States, we found that a considerable proportion shows negative evaluation scores regarding all three social dimensions (i.e. economic, political, or cultural). According to the relevant statistical values (principal component loadings and Cronbach's alpha), the respective anti-Americanism index (Table 1) is consistent and reliable.

We also saw that evaluations of economic and cultural phenomena are less dependent on short-term political developments. Thus the finding in previous studies (Meunier, 2012) that the ups and downs of antiAmericanism point to the impact of decisions made by the US administration has to be put into perspective. If we use a multidimensional instrument, significant shares of external effects are controlled for.

However, one might argue that the three-item instrument we used here is still insufficient as a measure of consistent anti-American attitudes. We recognize this 
objection, but we believe that this three-item index is by far the best measure that can be found in the literature so far.

A further objection could refer to our finding that antiAmerican attitudes are path-dependent: it might be possible that we have ignored a hidden factor $\mathrm{Z}$, which had an influence on attitudes earlier in history and still has an influence today. Maybe it is, for example, the geopolitical position of France and Germany as European superpowers that make them responsive for anti-Americanism, while Poland was and is in need of strong allies, and Britain traditionally finds itself in a transatlantic squeeze. Although at this point we are not able to test this rival hypothesis, we might be able to do so in a couple of years when the Polish integration into the European Union has advanced and Poland will have lost its precarious 'middle position'.

In regard to the theoretical mechanisms, it has to be stressed that the ones we suggested here offer only two ways of coping with the lack of theory in previous research. Approaches looking at the impact of morality, social norms, or the attitude/behaviour relationship (Ajzen, 1988) could be fruitful too. It is also difficult to measure the mechanisms of projection and cognitive dissonance directly. Although this holds true for many theoretical concepts in the social sciences, a study with primary data would be able to operationalize the concepts more precisely. Such a study could also apply a multi-item measure that offers more valid data on the proportion of anti-Americans in the respective countries.

Nevertheless, this study advances our understanding of anti-Americanism significantly: considerable proportions of Europeans seem to have negative opinions about US 'customs', 'ideas about democracy', and 'ways of doing business'. This aversion against America is mainly based on the broader social discontent with the market economy, the loss of tradition, and globalization.

In turbulent times, people seem to be in need of someone they can blame for the domestic problems they face. From the 18th century until today, America has been there to fulfil this role.

\section{Notes}

1. We chose France and Germany as examples because they are considered the 'birthplaces' of antiAmericanism (Ceaser, 2004). Britain, on the other hand, is seen as a cultural and political confederate of the United States. With Poland we include an Eastern European country to present a more heterogeneous picture. Apart from that, Poland is an interesting example due to its geopolitical location that made it one of the most contested nation states in Europe and led to a probably unique sympathy for the United States (in continental Europe), which was proven once more during the 2003 Iraq war when, unlike Germany and France, Poland, although parts of its public were engaged in protests against the war, actively supported the US troops (Gordon and Shapiro, 2004).

2. Note that we are using the concepts of coherent attitudes and resentment synonymously in this article. The latter is not identical with the more demanding concept of 'Ressentiment' introduced by Nietzsche (1878/2000) and extended by Scheler (1912/2004).

3. Katzenstein and Keohane's (2007) typology of 'AntiAmericanisms' is helpful in specifying the context in which certain aspects are more or less relevant. However, we prefer the singular in this article, because we want to highlight the common features of the resentment, treat milieu (education, income, political attitudes) as determinants, and measure the intensity of anti-Americanism with a cardinal and no nominal scale.

4. The term 'coherence' refers to the individual evaluation. It does not imply that every antiAmerican individual uses the same stereotypes or that anti-Americanism takes the same shape in every country, for example.

5. Compared with works with a sociological approach, those dealing with the historical origin of antiAmericanism are large in number and this article does not intend to add something new to this historical literature. We selected a small sample to illustrate the point that today's aversion against 'America' is a path-dependent phenomenon. Note also that this section does not offer a complete or representative picture of attitudes towards 'America' during the time under discussion. Anti-Americanism was rather the exception, not the rule, especially among 'regular people'. However, we think it is not imperative to discuss the Europeans' complete image of America in the 19th and 20th century to point out the elements of anti-Americanism.

6. It seems no coincidence that Freud picked up on the matter during the late 1920s. He was one of the first to identify the dialectics in modernity recognizable during that time in Europe and especially in the 
'verspätete Nation' (belated nation) of Germany (Plessner, 1959/1998).

7. The exact wording of the two items we refer to in the present section is: 'Please tell me if you have a very favourable, somewhat favourable, somewhat unfavourable or very unfavourable opinion of the United States'; '[...] of Americans'. We use a binary coded variable that distinguishes between 'favourable' and 'unfavourable'.

8. Nevertheless many authors and the Pew reports also use the 'opinions of the US' as an indicator of antiAmericanism (Pew, 2003, 2009). As we mentioned earlier, the continuing divide between substantial reflections on a conceptual level and the flawed application of those concepts in empirical studies is surprising.

9. In the Schreber case study, Freud describes the basic mechanism of 'projection' as a process where 'an internal perception is suppressed, and, instead, its content, after undergoing a certain kind of distortion, enters consciousness in the form of an external perception' (Freud, 1911/2003: p. 56).

10. There are some studies that have elaborated on the similarities and differences between antiAmericanism and anti-Semitism (Diner, 1996; Haury, 2005; Markovits, 2007b; Knappertsbusch and Kelle, 2010).

11. As Hollander's (2004) volume documents, there seems to be a domestic version of antiAmericanism that follows the same projective and cognitive function as, for example, its European counterpart. In this regard, of course, the contact hypothesis makes no sense and one has to suggest a much higher degree of denial and preference for consistency among domestic antiAmericans.

12. There are two main reasons for this. First, not all relevant questions were presented to all respondents in each country; for example, in 2007, only half of the sample answered the questions regarding antiAmericanism. Second, missing values (e.g. regarding income) reduce the number of cases.

13. In all cases, there is just one factor (principal component method) with an eigenvalue above 1 , and explained variances ranging from 0.50 (France) to 0.70 (Poland). Reliability coefficients (Cronbach's alpha) vary depending on the year and country between 0.49 (France) and 0.76 (Poland).
14. As the dependent variable consists of four values, an ordered logit model may have been the preferred choice. Indeed, we estimated the corresponding ordered logit models for all models presented in Table 2, and there are no apparent differences regarding the $t$ - and $z$-values and hence the significance of coefficients. Hence, we opted for the ordinary least square model, which is more common and easier to interpret. Moreover, we use weighted data in the multivariate analyses. We also estimated the models with non-weighted data due to the fact that it is by no means clear whether weighted data should generally be the preferred option (Winship and Radbill, 1994). Here, too, the results are stable. Moreover, as can be seen in the (see Table A1), the main results do not seem to be affected by the reduction of data due to missing values on relevant variables. The pattern of significant bivariate correlations between the index of anti-Americanism and the independent variables included in the regression fits the pattern of statistically significant determinants in the multivariate analysis presented in Table 2 .

\section{Acknowledgements}

Previous versions of this article have been presented at the European Union Studies Conference 2011 in Boston and at the Council for European Studies Conference 2011 in Barcelona where the authors received valuable feedback. The authors thank Andrei S. Markovits for insightful comments on a previous draft of this article and Richard Wike for first-hand access to the data of the PEW studies. Finally, we are grateful to the ESR reviewers for their suggestions. The usual disclaimers apply.

\section{Funding}

This work was supported by the Fritz Thyssen Foundation, grant Az. 10.10.1.111.

\section{References}

Ajzen, I. (1988). Attitudes, Personality and Behavior. Buckingham: Open University Press.

Antoszek, A. and Delaney, K. (2006). Poland: transmissions and translations. In Alexander, S. (Ed.), The Americanization of Europe: Culture, Diplomacy, and Anti-Americanism after 1945. New York: Berghahn Books, pp. 218-250. 
Bacevich, A. J. (2002). American Empire: The Realities and Consequences of U.S. Diplomacy. Harvard: Harvard University Press.

Behrends, J. C. (2005). Erfundene Feindschaft und exportierte Erfindung. Der spätstalinistische Antiamerikanismus als sowjetische Leiterzählung und polnische Propaganda. In Behrends, J. C., Klimó, A. V. and Poutrus, P. G. (Eds.), Antiamerikanismus im 20. Jahrhundert. Studien zu Ost- und Westeuropa. Bonn: Dietz, pp. 159-186.

Bergmann, W. and Heitmeyer, W. (2005). Communicating anti-Semitism-Are the 'boundaries of the speakable' shifting? Tel Aviver Jahrbuch für deutsche Geschichte, 33, 70-89.

Berman, R. A. (2008). Anti-Americanism in Europe: A Cultural Problem. Stanford: Hoover Press.

Ceaser, J. W. (2004). The philosophical origins of antiAmericanism in Europe. In Hollander, P. (Ed.), Understanding Anti-Americanism. Its Origins and Impact at Home and Abroad. Chicago: Ivan R. Dee, pp. $45-64$.

Chesler, P. (2005). The New Anti-Semitism: The Current Crisis and What We Must Do about it. New York: John Wiley and Sons.

Chiozza, G. (2008). A crisis like no other? AntiAmericanism at the time of the Iraq war. European Journal of International Relations, 15, 257-289.

Chiozza, G. (2009). Anti-Americanism and the American World Order. Baltimore: Johns Hopkins University Press.

Claussen, D. (2007). Is there a new anti-Americanism? Reflections on Germany in times of global simultaneity. In Judt, T. and Lacorne, D. (Eds.), With Us or Against us. Studies in Global Anti-Americanism. New York: Palgrave Macmillan, pp. 75-92.

Cunliffe, M. (1986). The anatomy of anti-Americanism. In Kroes, R. and Rossem, M. V. (Eds.), AntiAmericanism in Europe. Amsterdam: Free University Press, pp. 20-36.

Diner, D. (1996). America in the Eyes of the Germans: An Essay on Anti-Americanism. Princeton: Markus Wiener Publishers.

Eagly, A. H. and Chaiken, S. (1993). The Psychology of Attitudes. Fort Worth: Harcourt.

Fabbrini, S. (2004). Layers of anti-Americanism: Americanization, American unilateralism and antiAmericanism in a European perspective. European Journal of American Culture, 23, 79-94.

Festinger, L. (1957/1985). A Theory of Cognitive Dissonance. Stanford: Stanford University Press.

Freud, S. (1930/1997). Das Unbehagen in der Kultur: Und andere kulturtheoretische Schriften. Frankfurt: Fischer.
Freud, S. (1911/2003). The Schreber Case (translated by Andrew Webber, with an introduction by Colin McCabe). New York: Penguin Classics.

Friedman, M. P. (2008). Anti-Americanism and US foreign relations. Diplomatic History. Vol. 32, pp. 497-514.

Gentzkow, M. A. and Shapiro, J. M. (2004). Media, education and anti-Americanism in Muslim world. Journal of Economic Perspectives, 18, 117-133.

Gordon, P. H. and Shapiro, J. (2004). Allies At War: America, Europe and the Crisis Over Iraq. New York: McGraw-Hill.

Gross, J. T. (2007). Fear. Anti-Semitism in Poland After Auschwitz: An Essay in Historical Interpretation. New York: Random House.

Gulddal, J. (2009). That most hateful land: Romaticism and the birth of modern anti-Americanism. Journal of European Studies, 39, 419-454.

Hatlapa, R. and Markovits, A. S. (2010). Obamamania and anti-Americanism as complementary concepts in contemporary German discourse. German Politics and Society, 28, 69-94.

Haury, T. (2005). Ziehen die Fäden im Hintergrund, No-Globals, Antisemitismus und Antiamerikanismus. In Loewy, H. (Ed.), Gerüchte über die Juden. Antisemitismus, Philosemitismus und aktuelle Verschwörungstheorien. Essen: Klartext.

Hirsh, D. (2007). Anti-Zionism and Antisemitism: Cosmopolitan Reflections. New Haven: Yale Initiative for the Interdisciplinary Study of Antisemitism.

Hollander, P. (1992). Anti-Americanism, Critiques At Home And Abroad, 1965-1990. Oxford: Oxford University Press.

Hollander, P. (2004). Understanding Anti-Americanism. Its Origins and Impact at Home and Abroad. Chicago: Ivan R. Dee.

Holsti, O. (2008). To See Ourselves as Others See Us: How Publics Abroad View the United States After 9/11. Ann Arbor: University of Michigan Press.

Horkheimer, M. and Adorno, T. W. (1947/2002). Dialectic of Enlightenment: Philosophical Fragments. Stanford: Stanford University Press.

Inglehart, R. (1977). The Silent Revolution: Changing Values and Political Styles among Western Publics. Princeton: Princeton University Press.

Isernia, P. (2007). Anti-Americanism in Europe during the Cold War. In Katzenstein, P. J. and Keohane, R. O. (Eds.), Anti-Americanisms in World Politics. Ithaca: Cornell University Press, pp. 57-92.

Katzenstein, P. J. and Keohane, R. O. (2007). Varieties of anti-Americanism: A framework for analysis. In Katzenstein, P. J. and Keohane, R. O. (Eds.), Anti- 
Americanisms in World Politics. Ithaca: Cornell University Press, pp. 9-38.

Keohane, R. O. and Katzenstein, P. J. (2007). Introduction: The Politics of Anti-Americanisms. In Katzenstein, P. J. and Keohane, R. O. (Eds.), Anti-Americanisms in World Politics. Ithaca: Cornell University Press, pp. 1-8.

Knappertsbusch, F. and Kelle, U. (2010). 'Mutterland des nomadisierenden Finanzkapitals'_Zum Verhältnis von Antiamerikanismus und Antisemitismus vor dem Hintergrund der Finanzkrise. In Heitmeyer, W. (Ed.), Deutsche Zustände, Folge 8. Frankfurt: Suhrkamp, pp. 144-163.

Kohut, A. and Stokes, B. (2006). America Against the World: How We Are Different And Why We Are Disliked. New York: Times Books.

Krastev, I. (2004). The anti-American century? Journal of Democracy, 15, 5-16.

Krzemiński, A. (2004). Amerika und Polen. In Thadden, R. V. and Escudier, A. (Eds.), Amerika und Europa - Mars und Venus? Das Bild Amerikas in Europa. Goettingen: Wallstein Verlag, pp. $165-172$.

Markovits, A. S. (1985). On anti-Americanism in WestGermany. New German Critique, 34, 3-27.

Markovits, A. S. (2007a). Uncouth Nation: Why Europe Dislikes America. Princeton: Princeton University Press.

Markovits, A. S. (2007b). European anti-Semitism and anti-Americanism. In O'Connor, B. and Griffiths, M. (Eds.), Anti-Americanism: History, Causes, and Themes. Vol. 2: Historical Perspectives. Oxford: Greenwood, pp. 119-150.

Markovits, A. S. and Rensmann, L. (2007). AntiAmericanism in Germany. In O'Connor, B. (Ed.), Anti-Americanism: History, Causes, and Themes. Vol. 3: Comparative Perspectives. Oxford: Greenwood, pp. 155-182.

McAdam, D. (2007). Legacies of anti-Americanism: A sociological perspective. In Katzenstein, P. J. and Keohane, R. O. (Eds.), Anti-Americanisms in World Politics. Ithaca: Cornell University Press, pp. 251-272.

Meunier, S. (2007). The distinctiveness of French antiAmericanism. In Katzenstein, P. J. and Keohane, R. O. (Eds.), Anti-Americanisms in World Politics. Ithaca: Cornell University Press, pp. 129-156.

Meunier, S. (2012). The dog that did not bark: AntiAmericanism and the 2008 financial crisis in Europe. Review of International Political Economy, 20.1, 1-25.
Mosbacher, M. and Anderson, D. (2004). Recent trends in British anti-Americanism. In Hollander, P. (Ed.), Understanding Anti-Americanism. Its Origins and Impact at Home and Abroad. Chicago: Ivan R. Dee, pp. 84-104.

Nietzsche, F. (1878/2000). Menschliches Allzumenschliches. Frankfurt: Insel Verlag.

Nolan, M. (2005). Anti-Americanism and Americanization in Germany. Politics and Society, 33, 88-122.

Nye, J. S. (2004). Soft Power: The Means to Success in World Politics. New York: Public Affairs.

Pew Research Center for the People and the Press (2003). America's Image Further Erodes, Europeans Want Weaker Ties. But Post-War Iraq Will Be Better Off, Most Say. Washington: Pew.

Pew Research Center for the People and the Press (2009). Confidence in Obama Lifts U.S. Image Around the World. Washington: Pew.

Plessner, H. (1959/1998). Die verspätete Nation. Frankfurt: Suhrkamp.

Ray, L. and Johnston, G. (2007). European antiAmericanism and choices for a European defence policy. Political Science and Politics, 40, 85-91.

Roger, P. (2005). The American Enemy: The History of French Anti-Americanism. Chicago: University of Chicago Press.

Saguy, A. C., Kjerstin, G. and Gong, S. (2010). Social problem construction and national context: News reporting on 'overweight' and 'obesity' in the United States and France. Social Problems, 57, 586-610.

Scheler, M. (1912/2004). Das Ressentiment im Aufbau der Moralen. Frankfurt: Klostermann.

Schwaabe, C. (2003). Antiamerikanismus in Deutschland. Wandlungen eines Feindbildes. München: Fink.

Singh, R. (2007). Anti-Americanism in the United Kingdom. In O'Connor, B. (Ed.), AntiAmericanism: History, Causes, and Themes. Vol. 3: Comparative Perspectives. Oxford: Greenwood, pp. 183-212.

Spiro, H. J. (1988). Anti-Americanism in Western Europe. The Annals of the American Academy of Political and Social Science, 497, 120-132.

Volkov, S. (1978). Antisemitism as a cultural code: Reflections on the history and historiography of antisemitism in imperial Germany. Leo Baeck Institute Year Book, 23, 25-46.

Winship, C. and Radbill, L. (1994). Sampling Weights and Regression Analysis. Sociological Methods and Research, 23, 230-257. 


\section{Appendix}

Table A1 Bivariate correlations between anti-Americanism and proposed determinants

\begin{tabular}{|c|c|c|c|c|c|c|c|c|}
\hline \multirow[b]{2}{*}{ country/year } & \multicolumn{2}{|c|}{ Britain } & \multicolumn{2}{|c|}{ France } & \multicolumn{2}{|c|}{ Germany } & \multicolumn{2}{|c|}{ Poland } \\
\hline & 2002 & 2007 & 2002 & 2007 & 2002 & 2007 & 2002 & 2007 \\
\hline \multicolumn{9}{|l|}{ Social discontent } \\
\hline $\begin{array}{l}\text { Market economy better for } \\
\text { most }(1-4=\text { disagree })\end{array}$ & $\begin{array}{c}0.16^{* *} \\
344\end{array}$ & - & & - & $\begin{array}{c}0.17^{\star} \\
811\end{array}$ & - & $\begin{array}{c}0.20^{\star} \\
296\end{array}$ & $\begin{array}{c}0.23^{\star} \\
320\end{array}$ \\
\hline Tradition gets lost $(1=$ yes $)$ & $\begin{array}{c}0.26^{*} \\
349\end{array}$ & & $\begin{array}{l}0.13^{\star *} \\
457\end{array}$ & $\begin{array}{c}0.14^{\star *} \\
494\end{array}$ & $\begin{array}{l}0.11^{\star *} \\
812\end{array}$ & $\begin{array}{c}0.16^{*} \\
422\end{array}$ & & \\
\hline \multicolumn{9}{|l|}{ Globalization critique } \\
\hline $\begin{array}{l}\text { Growing business ties } \\
(1-4=\text { very bad })\end{array}$ & $\begin{array}{l}0.16^{\star *} \\
358\end{array}$ & $\begin{array}{c}0.16^{\star *} \\
305\end{array}$ & $\begin{array}{c}0.21^{*} \\
458\end{array}$ & $\begin{array}{c}0.13^{*} \\
493\end{array}$ & $\begin{array}{c}0.14^{*} \\
815\end{array}$ & $\begin{array}{c}0.23^{*} \\
423\end{array}$ & $\begin{array}{c}0.18^{* *} \\
307\end{array}$ & $\begin{array}{c}0.15^{* * *} \\
316\end{array}$ \\
\hline Influence of large companies & $0.24^{*}$ & $0.22^{*}$ & $0.20^{*}$ & $0.26^{*}$ & $0.21^{*}$ & $0.16^{*}$ & $0.19^{* *}$ & $0.20^{\star}$ \\
\hline$(1-4=$ very bad $)$ & 356 & 304 & 451 & 488 & 803 & 410 & 289 & 321 \\
\hline \multicolumn{9}{|l|}{ Anti-Zionism } \\
\hline $\begin{array}{l}\text { Palestinians cannot coexist } \\
\text { with Israel }(1=\text { yes })\end{array}$ & - & & - & & - & $\begin{array}{c}0.15^{\star *} \\
402\end{array}$ & - & $\begin{array}{c}0.25^{\star} \\
223\end{array}$ \\
\hline \multicolumn{9}{|l|}{ Visits to the United States } \\
\hline Ever traveled to the United & $-0.11^{\star \star *}$ & $-0.16^{\star \star *}$ & $-0.09^{* * *}$ & $-0.16^{\star}$ & & $-0.21^{*}$ & & \\
\hline States $(1=$ yes $)$ & 361 & 318 & 460 & 494 & & 402 & & \\
\hline \multicolumn{9}{|l|}{ Political attitude } \\
\hline $\begin{array}{l}\text { Higher values indicate a } \\
\text { right-wing attitude }\end{array}$ & & & $\begin{array}{c}-0.09^{* * *} \\
437\end{array}$ & $\begin{array}{c}-0.16^{*} \\
490\end{array}$ & & & & \\
\hline \multicolumn{9}{|l|}{ Sociodemographics } \\
\hline Gender $(1=$ female $)$ & & & & & & $\begin{array}{c}0.13^{\star * *} \\
427\end{array}$ & & \\
\hline Age in years & $\begin{array}{c}0.26^{*} \\
361\end{array}$ & $\begin{array}{c}0.16^{*} \\
314\end{array}$ & & & $\begin{array}{l}0.10^{* *} \\
821\end{array}$ & & $\begin{array}{c}0.22^{\star} \\
315\end{array}$ & $\begin{array}{c}0.20^{*} \\
331\end{array}$ \\
\hline \multicolumn{9}{|l|}{$\begin{array}{l}\text { Higher education } \\
\quad(1=\text { yes })\end{array}$} \\
\hline $\begin{array}{l}\text { High income class } \\
\quad(1=\text { yes })\end{array}$ & & & & & $\begin{array}{c}-0.08^{\star * *} \\
729\end{array}$ & $\begin{array}{l}-0.19^{*} \\
427\end{array}$ & & \\
\hline
\end{tabular}

Source: Reported are pairwise and statistically significant Pearson correlations between the anti-Americanism index and proposed determinants (first number gives the coefficient) as well as the number of respondents (second number); ${ }^{*} P<0.001,{ }^{* *} P<0.01,{ }^{* *} P<0.05$. 